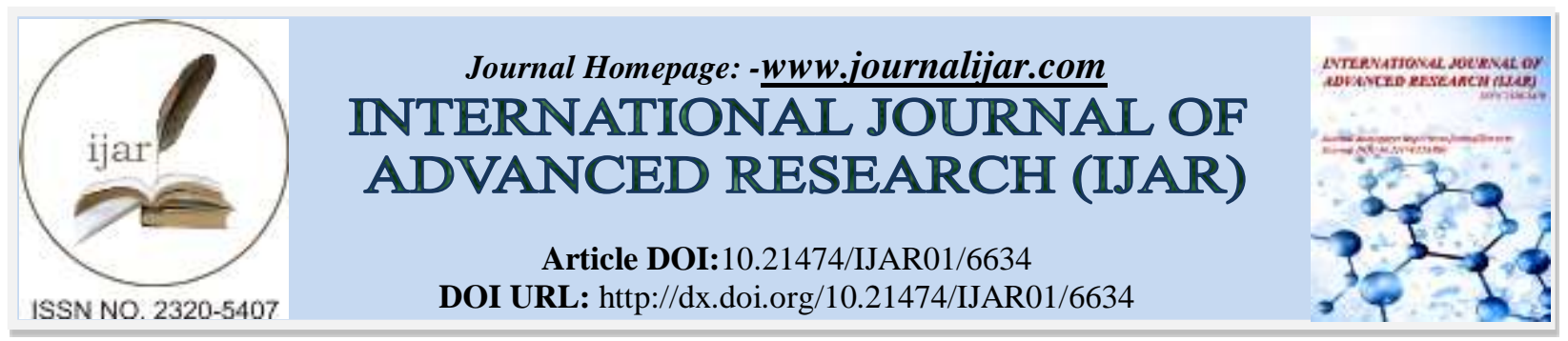

RESEARCH ARTICLE

\title{
REVIEW OF PSYCHOLOGICAL AND BEHAVIORAL FACTORS IN PEPTIC ULCER DISEASE.
}

\section{Yasar Sattar ${ }^{1}$, Anan Bseiso ${ }^{2}$, Nirav B Patel ${ }^{3}$, Daniel Azzopardi Larios ${ }^{4}$, Priscilla Tutu ${ }^{5}$, Sadiasept Vargas $^{6}$,} Vikram Kumar ${ }^{7}$, Sara Khan ${ }^{8}$, Sharaad Latchana ${ }^{9}$, Ziv Peretz ${ }^{10}$, Stefany Carolina Lopez Pantoja ${ }^{11}$ and Muhammad Nadeem ${ }^{12}$,

1. Kings County Hospital Brooklyn, USA.

2. College of Medicine, Alexandria University, Egypt.

3. AMC Met Medical College, India.

4. Kings County Hospital Brooklyn, USA.

5. Ross University School of Medicine, Dominic.

6. Instituto Technologico De Santo Domingo, Dominican Republic.

7. Sri Ramachandra University, India.

8. Dow Medical College, Pakistan.

9. American University of Integrative Sciences, USA.

10. Carol Davila University of Medicine, Romania.

11. Pontificia Universidad Catolica Del, Ecuador.

12. St. Francis Medical Center New Jersey, USA.

\section{Manuscript Info}

Manuscript History

Received: 25 December 2017

Final Accepted: 27 January 2018

Published: February 2018

Keywords:-

Peptic ulcer disease, PUD, peptic ulcer pathogenesis, psychological stress, psychiatric disorders, personality, behavior.

\section{Abstract}

Peptic Ulcer Disease (PUD) is a leading cause of morbidity and mortality, and it has been associated with various etiological factors. Whereas nonsteroidal anti-inflammatory drugs (NSAIDs) and Helicobacter pylori infection have taken prominent roles in recent discussions, many peptic ulcers remain idiopathic and this suggests that other important factors may play a role in their pathogenesis. Behavioral and social factors are known to cause and prevent the healing of PUD. The objective of this study is to demonstrate the influence of psychological and behavioral factors on the development of gastroduodenal ulcers and how they predominately affect the progression of ulcers. We found that psychological stress increases the incidence of peptic ulcer in many ways. Psychiatric conditions and personality disorders have an adverse effect on the integrity of the stomach and duodenum. Health risk behaviors such as cigarette smoking, alcohol consumption, irregular meal times, and short sleep duration, impair mucosal defenses and increase acid secretion. The mechanisms in which psychological and behavioral factors interact with other organic elements are not well understood, and future research addressing these aspects will broaden our knowledge on the prevention and treatment of PUD. 


\section{Introduction:-}

A 31-year-old man comes to the emergency department due to episodic abdominal pain. The pain is localized to the epigastrium and is gnawing in quality. It wakes him up during the night and is promptly relieved by a glass of water and a piece of bread. The patient has no associated vomiting or diarrhea but has experienced occasional dark stools. He was diagnosed with generalized anxiety disorder (GAD) eight years ago. Family history is insignificant for peptic ulcer disease (PUD). He smokes a pack of cigarettes daily and consumes a can of beer most days. Vital signs are within normal limits. Physical examination shows mild epigastric discomfort on deep palpation, but other findings are unremarkable.

This case shows a typical picture of peptic ulcer disease (PUD), which refers to ulcerations in the stomach or duodenum that are most commonly caused by Helicobacter pylori (H. pylori) infection or nonsteroidal antiinflammatory drugs (NSAIDs) [1]. It is one of the leading causes of morbidity and mortality worldwide, and it is associated with life-threatening complications including perforation, bleeding, and obstruction [2]. According to the most recent epidemiological studies, around $0.125-1 \%$ of people have peptic ulcer disease, and it affects approximately six million people in the United States annually [2, 3]. More than half of the world's population has H. pylori infection, but only a small proportion of them (around 5-10\%) develop ulcers [2, 4]. Furthermore, cigarette smoking, high alcohol consumption, genetic predisposition, and psychological factors all have been linked to the disease as contributing factors [4].

The term "idiopathic peptic ulcer" refers to a peptic ulcer which is not associated with an apparent cause and seems to have arisen spontaneously [5]. As many as $10 \%$ of ulcers are idiopathic and occur in people who had never been exposed to either $H$. pylori or NSAIDs [6]. Considering that most individuals who have $H$. pylori never develop an ulcer $[2,4]$, it becomes apparent that they are co-factors and alternative pathways for developing an ulcer, both of which could involve psychological stress.

This article is an attempt at understanding the relationship between psychological factors and peptic ulcer disease, and explaining how emotional stress and personal behaviors may affect the integrity of the stomach and duodenum in ways which eventually lead to the development of an ulcer. We explain some of the core knowledge about the pathogenesis of peptic ulcer disease and address the relations between some psychiatric and personality disorders and peptic ulceration. We also explore the association between socioeconomic strata and the prevalence of $H$. pylori and peptic ulceration.

\section{Method:-}

The authors conducted a search for relevant abstracts, papers, and articles published in different journals in PubMed, PubMed Central (PMC), Google Scholar, and Cochrane database. The authors reviewed and discussed inclusion or exclusion of each article and data collection. The information in figures and tables has been extracted from internet search engines and edited for simple interpretation.

Six hundred and fifty-seven references were initially accessed using "peptic ulcer disease", "PUD”, "peptic ulcer pathogenesis", "psychological stress", "psychiatric disorders", "personality" and "behavior" as search keywords, of which ninety-two references were shortlisted after excluding case reports, case series, individual animal modules, and complications of peptic ulcer. The search was further narrowed to fifty references by selecting articles related to the present review. Only articles in English were included, and preference was given to cross-sectional, cohort, prospective, retrospective, case-control studies, systematic review, and meta-analysis, in that order. Moreover, the search was focused on articles published in the last ten years.

\section{Discussion:-}

\section{The Biological Basis of Peptic Ulceration:-}

A peptic ulcer occurs when the destructive effect of gastric acid and enzymes overcomes the defense mechanisms of the gastrointestinal tract (mucus, bicarbonate, prostaglandins and blood flow) [7, 8]. Although ulcers more commonly cause a chronic gnawing or burning epigastric pain, which is sometimes accompanied by nausea, fullness, bloating and loss of appetite after eating a small amount of food [3], they may also present as a surgical emergency when perforation, penetration, bleeding or gastric outlet obstruction occur [9, 10]. 
A chronic gastric ulcer is usually single and most often located on the lesser curve within the antral mucosa or at the junction between the body and antrum [11]. By contrast, chronic duodenal ulcers are usually situated in the first part of the duodenum on the anterior wall [12]. Gastric and duodenal ulcers exist together in 0.1-1.7\% of patients [13]. The incidence of gastric and duodenal ulcers has declined significantly in the last forty years [14], partially because improved hygienic conditions, like oral health status, have led to a decrease in the storage and transmission of $H$. pylori infection [15], but possibly also because the widespread use of noninvasive $H$. pylori testing has lead to nonendoscopic diagnosis and treatment with underestimation in endoscopic PUD studies [16].

There is a genetic predisposition for developing PUD, and multiple factors play different roles [17]. Gastric hypersecretion is genetically determined and is a risk factor for duodenal ulceration [18]. There is a proven association between peptic ulcer and blood type $\mathrm{O}$ [19]. A variety of environmental factors affect the mucosal lining of the stomach and duodenum, including the gram-negative bacterium $H$. pylori, use of nonsteroidal antiinflammatory drugs such as ibuprofen, cigarette smoking, and heavy alcohol intake [4].

The mainstay treatment for an uncomplicated peptic ulcer is based on anti-secretory drugs and the eradication of $H$. pylori. The recommended regimen option for people who are infected with the bacterium (the vast majority of patients are $H$. pylori positive), is the triple therapy, which is seven days on proton pump inhibitors (PPIs), clarithromycin, and amoxicillin (metronidazole is an alternative antibiotic for patients who have penicillin allergy) [20]. Moreover, anti-secretory medications are the treatment of choice for NSAID-related peptic ulcers and are useful as preventive therapy in chronic users of NSAIDs [21]. The surgical management of peptic ulcer disease has markedly decreased because of the increased efficiency of the medical therapies, and surgery is now restricted to those patients who have recurrent, intractable or refractory disease [22, 23].

Despite the high cure rate that results after the use of triple therapy, this regimen is restricted to people who have $H$. pylori infection. Recent research and studies have proven that many ulcers occur in the absence of the organism and are termed "idiopathic ulcers". The treatment of these ulcers is challenging, because this type of ulcer tends to be resistant to standard therapy since eradication with antibiotics may fail to cure symptoms or prevent ulcer recurrence $[24,25]$. Therefore, research in this field is required to uncover new effective medications and regimens.

\section{Psychological Stress:-}

The relation between stress and physical health is a complicated process. Stress is a universal experience and can be of multiple intensities and of environmental, psychological and biological natures [26]. Stress triggers off different psychological, biological and behavioral responses in different individuals..

Like many other physical diseases, peptic ulcer has been linked to stress. Some studies have discussed the influence of psychological stress on the health of the upper gastrointestinal tract and they came up with close results. A prospective study of 3379 adults in a population-based Danish cohort reported that psychological stress increases the probability of developing a peptic ulcer [27]. The stress was measured by using a 0 to 10 point stress index scale, based on concrete life stressors and perceived distress. Another population-based cohort study in Taiwan recruited 218,319 healthcare workers (HCWs) with heavy, stressful workloads, rotating nightshifts, and on-call rosters, from Taiwan's National Health Insurance Research Database, and an identical number of non-HCW patients were randomly selected. There was a higher risk of PUD in healthcare workers, especially nurses, as compared to the general population [28].

There are multiple theories that connect the effects of stress with ulcer formation. One model suggests that the norepinephrine released during chronic stress causes capillary constriction in the lining of the stomach which decreases the mucosal vitality. There is a reduction in bicarbonate production and the washing out of hydrochloric acid, so the protective barrier of the stomach wall vanishes. Without this barrier, the acid destroys the lining of the stomach and duodenum and, in time, results in an ulcer. Another theory proposes that stress increases acid secretion and may lead to ulcer formation especially in subjects prone to peptic ulcer. However, some studies have suggested that stress might actually decrease acid secretion; this action is mediated by a nervous reflex involving a neuronal pathway that involves nitric oxide synthesis in the brain, specifically in the dorsal motor nucleus of the vagus nerve [30].

Stress has other local physiological impacts, other than increasing acid production and weakening the mucosal defense, which could contribute to its association with peptic ulcer disease. Stress inhibits gastric emptying and 
stimulates colonic motor function [31], and this may decrease the risk of duodenal ulcer and increase the risk of gastric ulcer. In fact, patients who suffer from duodenal ulcers characteristically have fast gastric emptying with increased amounts of acid arriving at the first part of the duodenum, suggesting that stress may decrease the risk of duodenal ulcer and increase the risk of gastric ulcer.

Psychological stress appears to increase the colonization with $H$. pylori and enhance the pathogenic and destructive effects of $H$. pylori infection. This effect may be mediated by increased secretion of glucocorticoid during stress and a poor immune response against the infection [32]. Similarly, raised glucocorticoid levels in stress interfere with wound healing and probably contribute to the poor healing of ulcers under stress (Figure 1) [33].

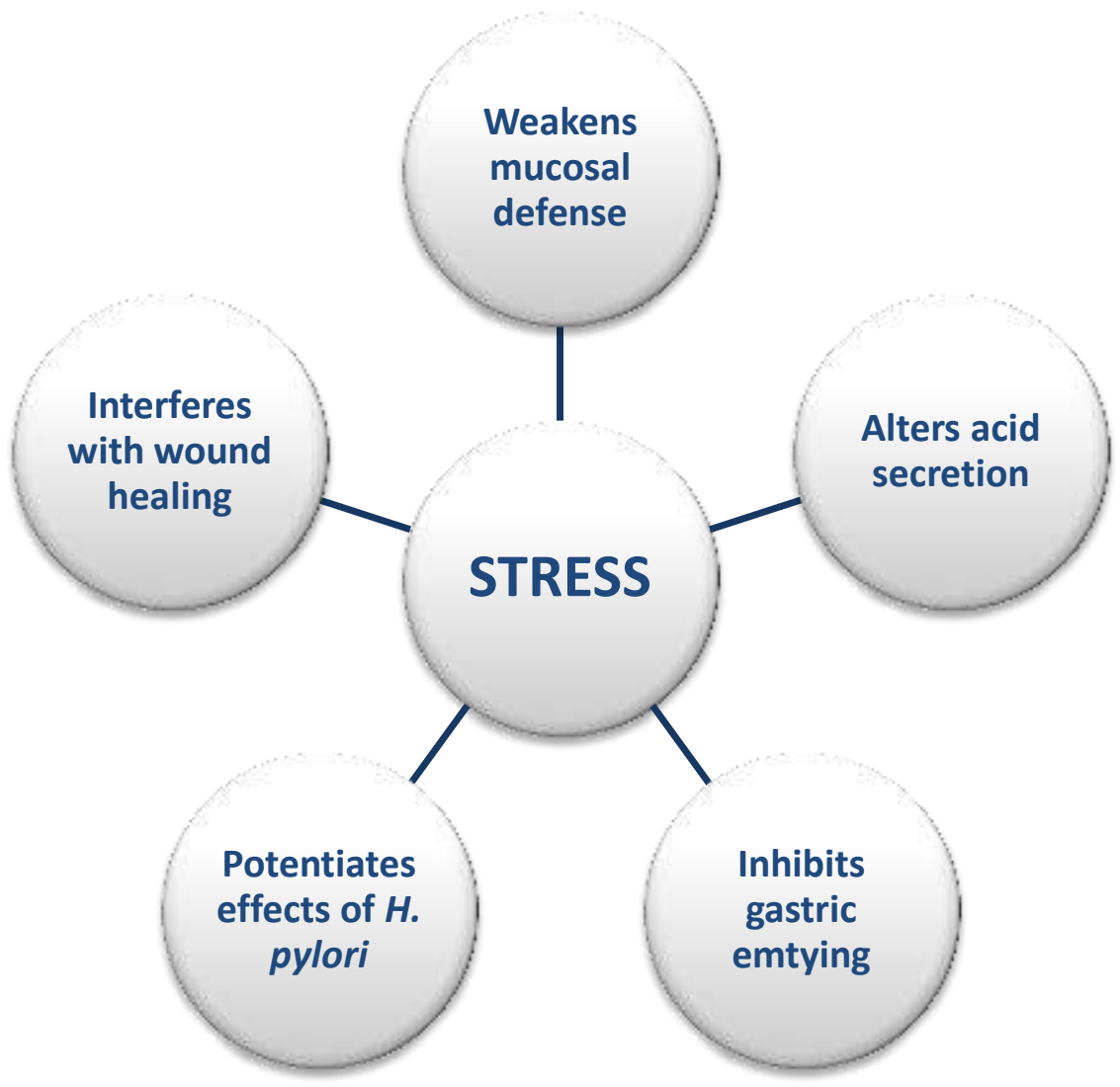

Figure 1:- Stress decreases the integrity of the gastrointestinal tract and allows for multiple mechanisms to interact and eventually cause ulceration. H. pylori: Helicobacter pylori.

\section{Psychiatric and Personality Disorders:-}

Many studies have tried to understand and demonstrate a relation between PUD and psychiatric disorders. One study was done in Taiwan to assess the association between unipolar depression and ulcer formation. It concluded that the incidence of PUD was twice as high in the depression cohort than in the comparison group [34]. Another study claimed that the relation between peptic ulcer and generalized anxiety disorder (GAD) is significant and better understood. It stated that GAD was strongly associated with an increased risk of self-reported PUD (with an odds ratio of 2.8) [35]. A weaker association was noticed between PUD and schizophrenia; a study reported that subjects with schizophrenia have a risk 1.27 times higher than the general population [36].

Interestingly, a research published in 2010 showed that people with stomach ulcer were five times more likely to have a personality disorder. All seven-personality disorders were assessed and the study was done on a large sample in the United States. There were positive but different associations for the specific types of personality disorder, with the strongest association between stomach ulcer and dependent personality disorder [37]. How personality disorders could have such an effect is not well understood, but there are multiple theories. One possibility is that certain personality types, like dependent personality, may be more likely to engage in problematic behaviors, such as 
smoking, drinking alcohol, sleeplessness and irregular meals [38]. Another theory is that some personality factors trigger a stress response, which has a well-recognized effect on the immune system and the development of ulcer [39].

\section{Behavior:-}

Risky behavior affects the integrity of the stomach and duodenum and tends to be more common in people who are experiencing life stressors. Cigarette smoking, alcohol consumption, and nonsteroidal anti-inflammatory drug (NSAID) use impair the defense mechanisms of the gastrointestinal tract [40], while irregular meals, shift work, and short sleep duration possibly increase the amount of acid in the duodenum (Figure 2). The use of NSAIDs increases under stress, perhaps due to worsening of painful conditions and higher requirements for analgesic medications. Smoking and nicotine have considerable adverse effects on the gastrointestinal tract. They stimulate gastric acid secretion, which is more obvious in smokers who have duodenal ulceration. This increase in stomach acid production is mediated by $\mathrm{H} 2$-receptor activation by histamine as well as an increase in parietal cell numbers, volume and secretory function. Chief cell numbers are also increased and pepsinogen is secreted in higher levels. Smoking potentiates ulceration caused by $\mathrm{H}$. pylori, alcohol, or nonsteroidal anti-inflammatory drugs by impairing the healing process of a previously formed ulcer. The mechanism is partially attributed to the inhibitory effect of smoking on the proliferation of gastric mucosal cells by decreasing ornithine decarboxylase activity. It also reduces prostaglandin production in the stomach, making the mucosa more susceptible to ulcer formation [41].

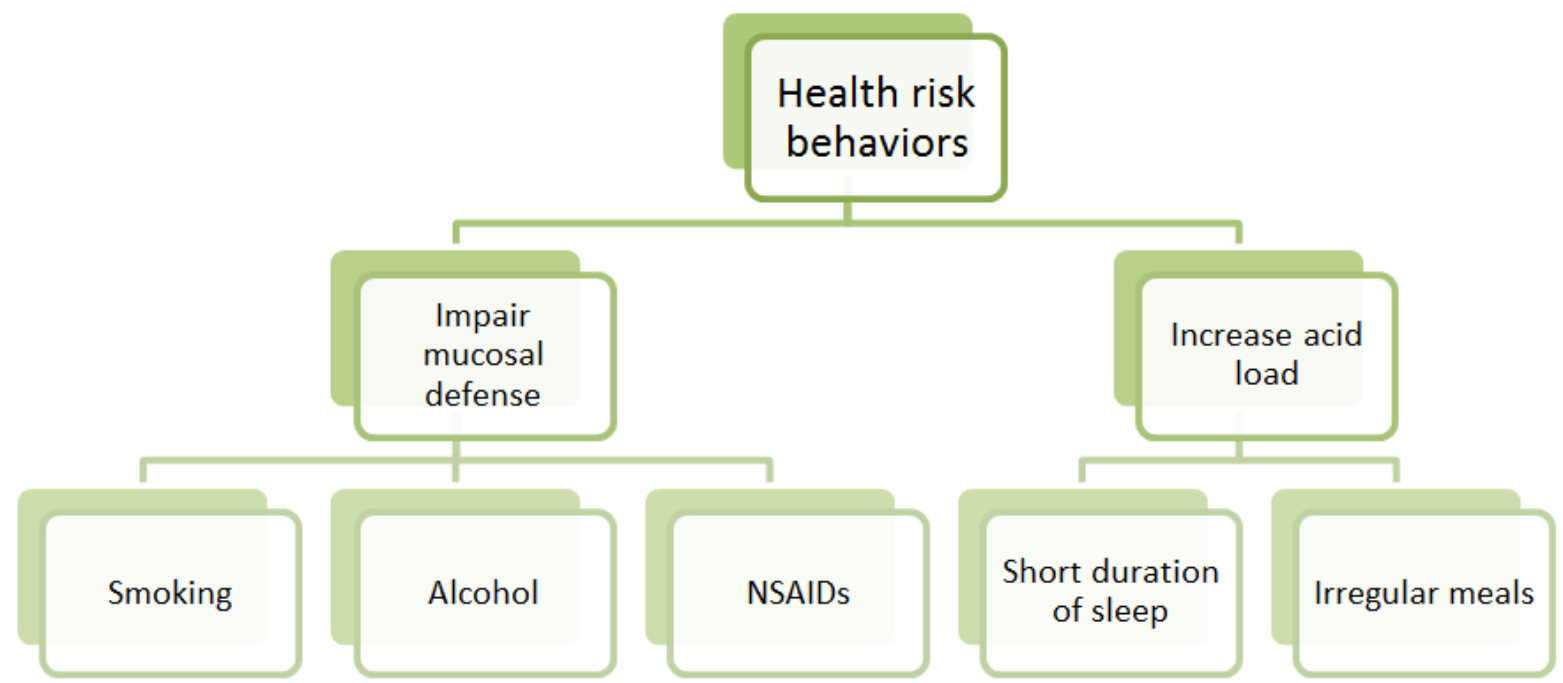

Figure 2:- The effects of health risk behaviors on the mucosal lining of stomach and duodenum They are two possible pathways of how health risk behaviors increase the incidence of peptic ulcer. Some bad behaviors impair mucosal defense, and other behaviors increase acid secretion. NSAIDs: Nonsteroidal anti-inflammatory drugs.

Many studies have demonstrated the role of diet in reducing or aggravating the risk of PUD. A few key food types are protective against ulceration, while others increase the risk. The most beneficial foods are fruits and vegetables due to their high content of fiber and vitamin A [42]. In contrast, a diet rich in milk and fat is associated with an increased risk of PUD [43]. The timing and regularity of meals appear to affect the mucosal lining of the stomach and duodenum. A study published in 2013 showed that frequent deviation in meal timing over a prolonged period and skipping breakfast are both associated with increased risk of PUD, in part due to increased colonization with $H$. pylori [44].

An association between physical activity and PUD has also been identified. Moderate and regular physical activities seem to reduce the incidence of duodenal ulcer [45]. Conversely, extreme physical exercise influences stomach function and can result in gastric ulceration [46]. Sleep and PUD have also been studied, and the prevalence of gastric and duodenal ulcers was higher in shift workers than daytime workers; shift work involves sleep disturbances, and this plays an important role in the development of peptic ulcer [47]. Longer sleep duration (more than nine hours) might play a protective role against PUD [48]. 


\section{Socioeconomic Status:-}

Ulcers are more common in low socioeconomic groups. The major responsible factor for this is $H$. pylori infection. H. pylori is acquired more easily in overcrowded houses and under conditions of poor hygiene. The epidemiology of $H$. pylori infection has noticeable differences between developing and developed countries, especially among children. In fact, low socioeconomic status and young age are the most two common determinant risk factors for $H$. pylori infection [49]. High prevalence of hard physical labor in families who have low income, poor education, and lower academic skills, is another possible contributing factor for increased incidence of peptic ulcer in low socioeconomic strata. Individuals with low socioeconomic status are more susceptible to health risk behaviors like smoking, heavy alcohol consumption, lack of sleep, skipping breakfast, and analgesic use. They tend to experience more stressful events in life as well (Table 1) [50].

\begin{tabular}{|c|c|c|c|c|c|}
\hline Author & Journal & Year & Type of study & Aim of study & Main findings \\
\hline $\begin{array}{l}\text { Namiot DB, } \\
\text { et al [14]. }\end{array}$ & $\begin{array}{l}\text { Advances in } \\
\text { Medical Sciences }\end{array}$ & 2006 & $\begin{array}{l}\text { Cross- } \\
\text { sectional } \\
\text { study }\end{array}$ & $\begin{array}{l}\text { To determine an } \\
\text { association } \\
\text { between the } \\
\text { prevalence of } \\
\text { peptic ulcer and } \\
\text { oral health status. }\end{array}$ & $\begin{array}{l}\text { Poor oral health is related to } \\
\text { the prevalence of PUD which } \\
\text { is not caused by NSAID } \\
\text { consumption, but it appears } \\
\text { doubtful that it is a significant } \\
\text { pathogenic factor in ulcer } \\
\text { disease. }\end{array}$ \\
\hline $\begin{array}{l}\text { Malaty HM, } \\
\text { et al [17]. }\end{array}$ & $\begin{array}{l}\text { Archives of } \\
\text { Internal Medicine }\end{array}$ & 2000 & $\begin{array}{l}\text { Cross- } \\
\text { sectional } \\
\text { study }\end{array}$ & $\begin{array}{l}\text { To assess the } \\
\text { importance of } \\
\text { genetic and } \\
\text { environmental } \\
\text { factors and the } \\
\text { importance of } H \text {. } \\
\text { pylori on peptic } \\
\text { ulcer disease. }\end{array}$ & $\begin{array}{l}\text { Genetic factors are of } \\
\text { moderate importance in the } \\
\text { pathogenesis of PUD. They } \\
\text { are independent of genetic } \\
\text { factors required for acquiring } \\
\text { H. pylori infection. }\end{array}$ \\
\hline $\begin{array}{l}\text { Edgren G, et } \\
\text { al [19]. }\end{array}$ & $\begin{array}{l}\text { American Journal } \\
\text { of Epidemiology }\end{array}$ & 2010 & Cohort study & $\begin{array}{l}\text { To evaluate an } \\
\text { association } \\
\text { between ABO } \\
\text { blood groups } \\
\text { versus gastric } \\
\text { cancer and peptic } \\
\text { ulcer. }\end{array}$ & $\begin{array}{l}\text { There is a relation between } \\
\text { blood group A and gastric } \\
\text { cancer. Individuals with blood } \\
\text { group O have a higher risk of } \\
\text { peptic ulcer disease than those } \\
\text { with other blood groups. }\end{array}$ \\
\hline $\begin{array}{l}\text { Levenstein } \\
S \text {, et al [27]. }\end{array}$ & $\begin{array}{l}\text { Clinical } \\
\text { Gastroenterology } \\
\text { and Hepatology }\end{array}$ & 2015 & Cohort study & $\begin{array}{l}\text { To determine a } \\
\text { relationship } \\
\text { between } \\
\text { psychological } \\
\text { stress and peptic } \\
\text { ulcers. }\end{array}$ & $\begin{array}{l}\text { Psychological stress increases } \\
\text { the risk of peptic ulcer, partly } \\
\text { by influencing health risk } \\
\text { behaviors. }\end{array}$ \\
\hline $\begin{array}{l}\text { Lin HY, et } \\
\text { al [28]. }\end{array}$ & Plos One & 2015 & Cohort study & $\begin{array}{l}\text { To estimate peptic } \\
\text { ulcer incidence in } \\
\text { health care } \\
\text { workers. }\end{array}$ & $\begin{array}{l}\text { Nurses and other health care } \\
\text { workers have a higher risk of } \\
\text { PUD than the general } \\
\text { population. }\end{array}$ \\
\hline $\begin{array}{l}\text { Hsu CC, et } \\
\text { al [34]. }\end{array}$ & $\begin{array}{l}\text { Medicine } \\
\text { (Baltimore) }\end{array}$ & 2015 & Cohort study & $\begin{array}{l}\text { To evaluate the } \\
\text { relationship } \\
\text { between } \\
\text { depression and } \\
\text { PUD. } \\
\end{array}$ & $\begin{array}{l}\text { Depression may increase the } \\
\text { risk of developing PUD. }\end{array}$ \\
\hline $\begin{array}{l}\text { Goodwin } \\
\text { RD, et al } \\
{[35] \text {. }}\end{array}$ & $\begin{array}{l}\text { Psychosomatic } \\
\text { medicine }\end{array}$ & 2002 & $\begin{array}{l}\text { Cross- } \\
\text { sectional } \\
\text { study }\end{array}$ & $\begin{array}{l}\text { To discuss the } \\
\text { association } \\
\text { between GAD and } \\
\text { self-reported } \\
\text { PUD. }\end{array}$ & $\begin{array}{l}\text { GAD was significantly } \\
\text { associated with self-reported } \\
\text { PUD. }\end{array}$ \\
\hline Liao $\mathrm{CH}$, et & Journal of & 2014 & Case-control & To evaluate the & Schizophrenia is associated \\
\hline
\end{tabular}




\begin{tabular}{|c|c|c|c|c|c|}
\hline al [36]. & $\begin{array}{l}\text { Psychosomatic } \\
\text { Research }\end{array}$ & & study & $\begin{array}{l}\text { relationship } \\
\text { between peptic } \\
\text { ulcer and } \\
\text { schizophrenia. }\end{array}$ & $\begin{array}{l}\text { with a slightly higher risk of } \\
\text { PUD compared to the general } \\
\text { population. }\end{array}$ \\
\hline $\begin{array}{l}\text { Schuster JP, } \\
\text { et al [37]. }\end{array}$ & $\begin{array}{l}\text { Psychosomatic } \\
\text { Medicine }\end{array}$ & 2010 & $\begin{array}{l}\text { Cross- } \\
\text { sectional } \\
\text { study }\end{array}$ & $\begin{array}{l}\text { To determine the } \\
\text { association } \\
\text { between PUD and } \\
\text { a wide range of } \\
\text { personality } \\
\text { disorders. }\end{array}$ & $\begin{array}{l}\text { PUD is associated with } \\
\text { increased rates of personality } \\
\text { disorders, beyond the } \\
\text { influence of psychiatric } \\
\text { disorders or addictions. }\end{array}$ \\
\hline $\begin{array}{l}\text { Ryan- } \\
\text { Harshman } \\
\text { M, et al } \\
{[42] .}\end{array}$ & $\begin{array}{l}\text { Canadian Family } \\
\text { Physician }\end{array}$ & 2004 & Review article & $\begin{array}{l}\text { To discuss the role } \\
\text { of diet in reducing } \\
\text { or increasing the } \\
\text { risk of duodenal } \\
\text { ulcer. }\end{array}$ & $\begin{array}{l}\text { A high-fiber diet, especially } \\
\text { from fruits and vegetables, } \\
\text { might reduce the risk of } \\
\text { duodenal ulcer; vitamin A may } \\
\text { also be beneficial. }\end{array}$ \\
\hline $\begin{array}{l}\text { Lim SL, et } \\
\text { al [44]. }\end{array}$ & ISRN Nutrition & 2013 & $\begin{array}{l}\text { Retrospective } \\
\text { study }\end{array}$ & $\begin{array}{l}\text { To decide whether } \\
\text { irregular meal } \\
\text { timing is } \\
\text { associated with } \\
\text { increased risk of } \\
\text { gastritis and } H \text {. } \\
\text { pylori infection. }\end{array}$ & $\begin{array}{l}\text { Frequent deviation in meal } \\
\text { timing over a prolonged period } \\
\text { may be related to an increased } \\
\text { risk of developing } H \text {. pylori } \\
\text { infection and gastritis. }\end{array}$ \\
\hline $\begin{array}{l}\text { Cheng Y, et } \\
\text { al [45]. }\end{array}$ & $\begin{array}{l}\text { Western Journal } \\
\text { of Medicine }\end{array}$ & 2000 & $\begin{array}{l}\text { Cross- } \\
\text { sectional } \\
\text { study }\end{array}$ & $\begin{array}{l}\text { To explore the } \\
\text { role of physical } \\
\text { activity in the } \\
\text { incidence of PUD. }\end{array}$ & $\begin{array}{l}\text { Moderate physical activity is a } \\
\text { protective factor against } \\
\text { duodenal ulcers. }\end{array}$ \\
\hline $\begin{array}{l}\text { Segawa K, } \\
\text { et al [47]. }\end{array}$ & $\begin{array}{l}\text { Digestive } \\
\text { Diseases and } \\
\text { Sciences }\end{array}$ & 1987 & $\begin{array}{l}\text { Cross- } \\
\text { sectional } \\
\text { study }\end{array}$ & $\begin{array}{l}\text { To demonstrate } \\
\text { the role of sleep } \\
\text { disturbances in the } \\
\text { pathogenesis of } \\
\text { PUD. }\end{array}$ & $\begin{array}{l}\text { The prevalence of PUD is } \\
\text { higher with shift workers than } \\
\text { daytime workers. }\end{array}$ \\
\hline $\begin{array}{l}\text { Ko SH, et al } \\
{[48] .}\end{array}$ & Scientific Reports & 2016 & $\begin{array}{l}\text { Cross- } \\
\text { sectional } \\
\text { study }\end{array}$ & $\begin{array}{l}\text { To determine the } \\
\text { relationship } \\
\text { between sleep } \\
\text { duration and PUD. }\end{array}$ & $\begin{array}{l}\text { Long sleep duration may play } \\
\text { a protective role in the } \\
\text { development of PUD. }\end{array}$ \\
\hline $\begin{array}{l}\text { Levenstein } \\
S \text {, et al [50]. }\end{array}$ & $\begin{array}{l}\text { Journal of Clinical } \\
\text { Gastroenterology }\end{array}$ & 1998 & Cohort study & $\begin{array}{l}\text { To discover } \\
\text { factors that may } \\
\text { play a role in the } \\
\text { association } \\
\text { between PUD and } \\
\text { low } \\
\text { socioeconomic } \\
\text { status. }\end{array}$ & $\begin{array}{l}\text { Psychological stress, risky } \\
\text { health behaviors, NSAID use, } \\
\text { and strenuous physical activity } \\
\text { may increase the risk of ulcer } \\
\text { in low socioeconomic groups. }\end{array}$ \\
\hline
\end{tabular}

Table 1:- Important studies concerning the pathogenesis of peptic ulcer disease and some associated risk factors. H. pylori: Helicobacter pylori. NSAIDs: Nonsteroidal anti-inflammatory drugs. GAD: Generalized anxiety disorder.

\section{Conclusion:-}

Psychological and behavioral factors influence the progression of PUD significantly. Due to a lack of organic cause in many patients with PUD, it has become widely accepted that there are multiple factors and other pathways that are involved in this process. Stress affects the mucosal lining of the stomach and duodenum and eventually leads to ulceration or potentiation of an already existing ulcer. Personality disorders play a negative role as well. Behaviors such as smoking and alcohol consumption impair mucosal defense, while irregular eating times and short sleep duration increase acid secretion. 
The interaction between psychological factors and organic causes is not clearly understood. However, the clinical importance of this study is to aid physicians and patients to understand the relation between PUD and psychological and behavioral factors, and identify risk-reduction strategies that can be implemented to diminish the risk of developing an ulcer. Despite the effectiveness of medical and surgical therapies in controlling peptic ulcer, further research is needed in areas such as psychology and behavioral sciences to get a better understanding of the disease and to construct a multifaceted approach to therapy, prevention and treatment.

\section{References:-}

1. Fashner J, Gitu AC: Diagnosis and treatment of peptic ulcer disease and H. pylori Infection. Am Fam Physician. 2015, 91:236-242. http://www.aafp.org/afp/2015/0215/p236.html

2. Cryer B, Mahaffey K: Gastrointestinal ulcers, role of aspirin, and clinical outcomes: pathobiology, diagnosis, and treatment. J Multidiscip Healthc. 2014, 7:137-146. 10.2147/JMDH.S54324

3. Gurusamy K, Pallari E: Medical versus surgical treatment for refractory or recurrent peptic ulcer. Cochrane Database of Systematic Reviews. 2016, 3:CD011523. 10.1002/14651858.CD011523.pub2

4. Prabhu V, Shivani A: An overview of history, pathogenesis and treatment of perforated peptic ulcer disease with evaluation of prognostic scoring in adults. Ann Med Health Sci Res. 2014, 4:22-29. https://www.ncbi.nlm.nih.gov/pmc/articles/PMC3952291/

5. Chung CS, Chiang TH, Lee YC: A systematic approach for the diagnosis and treatment of idiopathic peptic ulcers. Korean J Intern Med. 2015, 30:559-570. 10.3904/kjim.2015.30.5.559

6. Uyanikoğlu A, Danalioğlu A, Akyüz F, et al: Etiological factors of duodenal and gastric ulcers. Turk J Gastroenterol. 2012, 23:99-103. 10.4318/tjg.2012.0435

7. Mejia A, Kraft W: Acid peptic diseases: pharmacological approach to treatment. Expert Rev Clin Pharmacol. 2009, 2:295-314. 10.1586/ecp.09.8

8. Wallace JL: Prostaglandins, NSAIDs, and gastric mucosal protection: why doesn't the stomach digest itself?. Physiological Reviews. 2008, 88:1547-1565. 10.1152/physrev.00004.2008

9. Milosavljevic T, Kostić-Milosavljević M, Jovanović I, Krstić M: Complications of peptic ulcer disease. Dig Dis. 2011, 29:491-493. 10.1159/000331517

10. Chung K, Shelat V: Perforated peptic ulcer - an update. World J Gastrointest Surg. 2017, 9:1-12. 10.4240/wjgs.v9.i1.1

11. Saito J: [Studies on predilection area of gastric ulcer viewed from healing process of experimental gastric ulcers (author's transl)]. Nihon Heikatsukin Gakkai Zasshi . 1978, 14:105-118. 10.1540/jsmr1965.14.105

12. Al-Assi MT, Genta RM, Karttunen TJ, Graham DY: Ulcer site and complications: relation to Helicobacter pylori infection and NSAID use. Endoscopy. 1996, 28:229-233. 10.1055/s-2007-1005433

13. Ubukata H, Nagata H, Tabuchi T, Konishi S, Kasuga T, Tabuchi T: Why is the coexistence of gastric cancer and duodenal ulcer rare? examination of factors related to both gastric cancer and duodenal ulcer. Gastric Cancer. 2011, 14:4-12. 10.1007/s10120-011-0005-9

14. Namiot DB, Namiot Z, Kemona A, Gołebiewska M: Peptic ulcers and oral health status. Adv Med Sci. 2006, 51:153-155. https://www.ncbi.nlm.nih.gov/pubmed/17357297

15. Al Asqah M, Al Hamoudi N, Anil S, Al jebreen A, Al-hamoudi WK: Is the presence of Helicobacter pylori in the dental plaque of patients with chronic periodontitis a risk factor for gastric infection? . Can J Gastroenterol. 2009, 23:177-179. 10.1155/2009/950527

16. McJunkin B, Sissoko M, Levien J, Upchurch J, Ahmed A: Dramatic decline in prevalence of Helicobacter pylori and peptic ulcer disease in an endoscopy-referral population. Am J Med. 2011, 124:260-264. 10.1016/j.amjmed.2010.11.013

17. Malaty HM, Graham DY, Isaksson I, Engstrand L, Pedersen NL: Are genetic influences on peptic ulcer dependent or independent of genetic influences for Helicobacter pylori infection? . Am J Med. 2000, 160:105109. 10.1001/archinte.160.1.105

18. Osefo N, Ito T, Jensen R: Gastric acid hypersecretory states: recent insights and advances. Curr Gastroenterol Rep. 2009, 11:433-441. 10.1007/s11894-009-0067-6

19. Edgren G, Hjalgrim H, Rostgaard K, Norda R, Wikman A, Melbye M, Nyrén O: Risk of gastric cancer and peptic ulcers in relation to ABO blood type: a cohort study. Am J Epidemiol. 2010, 172:1280-1285. 10.1093/aje/kwq299

20. Gisbert JP, Pajares JM: Helicobacter pylori infection and perforated peptic ulcer prevalence of the infection and role of antimicrobial treatment. Helicobacter. 2003, 8:159-167. 10.1046/j.1523-5378.2003.00139.x

21. Pilotto A, Franceschi M, Maggi S, Addante F, Sancarlo D: Optimal management of peptic ulcer disease in the elderly. Drugs Aging. 2010, 27:545-558. 10.2165/11537380-000000000-00000 
22. Kim H: Diagnostic and treatment approaches for refractory peptic ulcers. Clin Endosc. 2015 , 48:285-290. 10.5946/ce.2015.48.4.285

23. Napolitano L: Refractory peptic ulcer disease. Gastroenterol Clin North Am. 2009, 38:267-288. 10.1016/j.gtc.2009.03.011

24. Quan C, Talley NJ: Management of peptic ulcer disease not related to Helicobacter pylori or NSAIDs. Am J Gastroenterol. 2002, 97:2950-2961. 10.1016/s0002-9270(02)05485-0

25. Iijima K, Kanno T, Koike T, Shimosegawa T: Helicobacter pylori-negative, non-steroidal anti-inflammatory drug: negative idiopathic ulcers in Asia. World J Gastroenterol. 2014, 20:706-713. 10.3748/wjg.v20.i3.706

26. Salleh M: Life event, stress and illness. Malays J Med Sci. 2008, 15:9-18. https://www.ncbi.nlm.nih.gov/pmc/articles/PMC3341916/

27. Levenstein S, Rosenstock S, Jacobsen RK, Jorgensen T: Psychological stress increases risk for peptic ulcer, regardless of Helicobacter pylori infection or use of nonsteroidal anti-inflammatory drugs. . Clin Gastroenterol Hepatol. 2015, 13:498-506. 10.1016/j.cgh.2014.07.052

28. Lin HY, Weng SF, Lin HJ, et al: Peptic ulcer disease in healthcare workers: a nationwide population-based cohort study. PLoS One. 2015, 10:e0135456. 10.1371/journal.pone.0135456

29. Krejci V, Hiltebrand LB, Sigurdsson GH: Effects of epinephrine, norepinephrine, and phenylephrine on microcirculatory blood flow in the gastrointestinal tract in sepsis. Crit Care Med. 2006, 34:14561463.https://insights.ovid.com/pubmed?pmid=16557162

30. Esplugues JV, Barrachina, Beltrán B, Calatayud S, Whittle BJR, Moncada S: Inhibition of gastric acid secretion by stress: a protective reflex mediated by cerebral nitric oxide. Proc Natl Acad Sci U S A. 1996, 93:14839-14844. 10.1073/pnas.93.25.14839

31. Taché Y, Martinez V, Million M, Wang L: Stress and the gastrointestinal tract III. Stress-related alterations of gut motor function: role of brain corticotropin-releasing factor receptors. Am J Physiol Gastrointest Liver Physiol. 2001, 280:173-177.http://ajpgi.physiology.org/content/280/2/G173

32. Guo G, Jia KR, Shi Y, et al: Psychological stress enhances the colonization of the stomach by Helicobacter pylori in the BALB/c mouse. Am J Physiol Gastrointest Liver Physiol. 2009, 12:478-485. $10.3109 / 10253890802642188$

33. Gouina JP, Kiecolt-Glaser JK: The impact of psychological stress on wound healing: methods and mechanisms. Immunol Allergy Clin North Am. 2011, 31:81-93. 10.1016/j.iac.2010.09.010

34. Hsu CC, Hsu YC, Chang KH, et al: Depression and the risk of peptic ulcer disease. Medicine (Baltimore). 2015, 94:e2333. https://www.ncbi.nlm.nih.gov/pmc/articles/PMC4697991/

35. Goodwin RD, Stein MB: Generalized anxiety disorder and peptic ulcer disease among adults in the United States. Psychosom Med. 2002, 64:862-866. https://insights.ovid.com/pubmed?pmid=12461190

36. Liao $\mathrm{CH}$, Chang CS, Chang SN, et al: The association of peptic ulcer and schizophrenia: a population-based study. J Psychosom Res. 2014, 77:541-546. 10.1016/j.jpsychores.2014.08.005

37. Schuster JP, Limosin F, Levenstein S, Le Strat Y: Association between peptic ulcer and personality disorders in a nationally representative US sample. Psychosom Med. 2010, 72:941-946. https://insights.ovid.com/pubmed?pmid=20716707

38. Gerhardstein K, Griffin P, Hormes J: Personality disorders lead to risky behavior, treatment obstacles. HIV Clin. 2011, 23:6-7. https://www.ncbi.nlm.nih.gov/pmc/articles/PMC4551451/

39. Stojanovich L, Marisavljevich D: Stress as a trigger of autoimmune disease. Autoimmun Rev. 2008, 7:209-213. 10.1016/j.autrev.2007.11.007

40. Matsui H, Shimokawa O, Kaneko T, Nagano Y, Rai K, Hyodo I: The pathophysiology of non-steroidal antiinflammatory drug (NSAID)-induced mucosal injuries in stomach and small intestine. J Clin Biochem Nutr. 2011, 48:107-111. 10.3164/jcbn.10-79

41. Maity P, Biswas K, Roy S, Banerjee RK, Bandyopadhyay U: Smoking and the pathogenesis of gastroduodenal ulcer--recent mechanistic update. Mol Cell Biochem. 2003, 253:329-338. https://link.springer.com/article/10.1023/A\%3A1026040723669

42. Ryan-Harshman M, Aldoori W: How diet and lifestyle affect duodenal ulcers. Review of the evidence. Can Fam Physician. 2004, 50:727-732. https://www.ncbi.nlm.nih.gov/pmc/articles/PMC2214597/

43. Elmståhl S, Svensson U, Berglund G: Fermented milk products are associated to ulcer disease. Results from a cross-sectional population study. Eur J Clin Nutr. 1998, 52:668-674. 10.1038/sj.ejcn.1600619

44. Lim SL, Canavarro C, Zaw MH, Zhu F, Loke WC, Chan YH, Yeoh KG: Irregular meal timing is associated with Helicobacter pylori infection and gastritis. ISRN Nutr. 2012, 2013:714970. 10.5402/2013/714970

45. Cheng Y, Macera C, Davis D, Blair S: Physical activity and peptic ulcers. West J Med. 2000, 173:101-107. https://www.ncbi.nlm.nih.gov/pmc/articles/PMC1071012/ 
46. Overmier J, Murison R: Restoring psychology's role in peptic ulcer. Appl Psychol Health Well Being. 2012, 5:5-27. 10.1111/j.1758-0854.2012.01076.x

47. Segawa K, Nakazawa S, Tsukamoto Y, et al: Peptic ulcer is prevalent among shift workers. Dig Dis Sci. 1987, 32:449-453. 10.1007/bf01296025

48. Ko SH, Baeg MK, Ko SY, Han KD: Women who sleep more have reduced risk of peptic ulcer disease; korean national health and nutrition examination survey (2008-2009). Sci Rep. 2016, 6:36925. 10.1038/srep36925

49. Khalifa M, Sharaf R, Aziz R: Helicobacter pylori: a poor man's gut pathogen? . Gut Pathog. 2010, 2:2. 10.1186/1757-4749-2-2

50. Levenstein S, Kaplan GA: Socioeconomic status and ulcer. A prospective study of contributory risk factors. J Clin Gastroenterol. 1998, 26:14-17. https://insights.ovid.com/pubmed?pmid=9492856. 